\title{
Feasibility of Storing Carbon Dioxide on a Tectonically Active Margin: New Zealand*
}

\author{
B.D. Field ${ }^{1,2}$, M.J. Lawrence ${ }^{1,2}$, A. Nicol ${ }^{1,2}$, D. McNamara ${ }^{2}$, M.J. Arnot ${ }^{2}$, F. Coyle ${ }^{1,2}$, K.E. Higgs ${ }^{1,2}$, B. Mountain ${ }^{1,2}$, M. Gerstenberger ${ }^{1,2}$, \\ R. Daniel ${ }^{1,3}$, M.A. Bunch ${ }^{1,3}$, and B. Barton ${ }^{4}$
}

\author{
Search and Discovery Article \#80527 (2016)** \\ Posted April 11, 2016
}

\begin{abstract}
**Datapages (C) 2016. Serial rights given by author. For all other rights contact author directly.
${ }^{1}$ CO2CRC at GNS Science, Lower Hutt, New Zealand (brad.field@gns.cri.nz)

${ }^{2}$ GNS Science, Wellington, New Zealand

${ }^{3}$ CO2CRC at Australian School of Petroleum, University of Adelaide, Adelaide, SA, Australia

${ }^{4}$ Faculty of Law, University of Waikato, Hamilton, New Zealand
\end{abstract}

*Adapted from oral presentation given at AAPG International Conference \& Exhibition, Melbourne, Australia, September 13-15, 2015.

\begin{abstract}
Screening of New Zealand's sedimentary basins indicates several gigatonnes of carbon dioxide storage capacity might be available. However, carbon dioxide storage is currently untested in New Zealand, and it is likely that most theoretical storage capacity will be discounted once detailed assessments are made. New Zealand's position on an active Neogene plate boundary raises additional key factors that will affect final site selection. Issues specific to New Zealand's setting include:

1. rapid facies changes, syndeposition and post-depositional structural events, particularly in regions close to the plate boundary;

2. rapid subsidence and high sedimentation rates leading to overpressured reservoirs and strong water drive in some structures, which will potentially result in injectivity issues, particularly in depleted fields;

3. mineralogically immature reservoir rocks requiring assessment of injected gas-rock reactions;

4. common occurrence of faults of various scales, requiring assessments of their sealing capacity and present stress fields; and

5. distinguishing induced seismicity from common natural seismicity. Some of these risk factors will also influence the relationship between social acceptance and the design of regulations.

Despite the risks, hydrocarbon-producing fields in Taranaki indicate that viable reservoir-seal pairs are likely to be present. Additionally, injection of small volumes of produced water and significant natural gas storage at the depleted Ahuroa Field have not led to noticeable induced seismicity, though large volumes expected from a carbon dioxide injection project would likely require careful site assessment for seismic risk in some areas. Natural analogue and laboratory fluid-rock experiments are investigating the effects of carbon dioxide injection on reservoir mineralogy, and some effects can now be anticipated. Currently produced gas from New Zealand locally contains significant carbon dioxide (up to $44 \%$ carbon dioxide in the Taranaki region and up to 30\% in the Canterbury Basin) and if new discoveries also have a high carbon dioxide content, they may require processing before use, with disposal of carbon dioxide. Such a large gas discovery anywhere in New Zealand could, therefore, stimulate rapid deployment of CCS. It is highly likely viable storage sites exist, particularly away from the current plate boundary, though the site-specific nature of site assessment is particularly important in New Zealand's geological context.
\end{abstract}




\section{Selected References}

Barton, B., K. Jordan, and G. Severinsen, 2013, Carbon capoture and storage: Designing the legal and re3gulatory framework for New Zealand: Report for Ministry of Business, Innovation and Employment and the New Zealand Carhon Capture and Storage Partnership.

Coyle, F., 2014, Tackling climate change: Small-scale deliberative engagement with Taranaki community stakeholders on carbon capture and storage (CCS): CO2CRC Report no. RPT14-5134, 187p.

Darby, D., R. Funnell, and K. Higgs, 2006, CO2 sequestration in New Zealand: Current work, opportunities and challenges, in 2006 New Zealand Petroleum Conference proceedings: Ministry of Economic Development, Wellington.

Darby, D., R.H. Funnell, and V. Stagpoole, 2000, Overpressure, seal breaching and stress regimes in East Coast and Taranaki basins, New Zealand (abstract): AAPG Bulletin, v. 84/9, p. 1416; Search and Discovery Article \# 90913 (2000). Website accessed March 25, 2016, http://www.searchanddiscovery.com/abstracts/html/2000/intl/abstracts/084.htm.

Field, B.D.; M.J. Arnot, J.G. Begg, K.J. Bland, M. Bunch, B.J. Doody, S.W. Edbrooke, R. Faulkner, R.H. Funnell, A.G. Griffin, K.E. Higgs, P.R. King, M.S. Rattenbury, B. Ricketts, amd D.P. Strogen, 2009, New Zealand carbon dioxide storage site assessment. Phase 2: GNS Science consultancy report 2009/217; CO2CRC Report RPT09-1579, 50 p.

Field, B.D., et al., 2011, Geological transect across the Wairoa area: Insights into elements of the East Coast petroleum system: GNS Science data series 11a. $1 \mathrm{CD}$.

Hulston, J.R., 1999, Factors controlling carbon isotopes in TVZ and Taranaki methanes: 16th New Zealand Geochemical Group Biennial Conference Proceedings and Field Trip Guide, Wellington, July 12-14, 1999.

Hulston, J.R.; D.R. Hilton, and I.R. Kaplan, 2001, Helium and carbon isotope systematics of natural gases from Taranaki Basin, New Zealand: Applied geochemistry, v. 16/4, p. 419-436.

King, P., K. Bland, R. Funnell, R. Archer, and L. Lever, 2009, Opportunities for underground geological storage of $\mathrm{CO}_{2}$ in New Zealand Report CCS-08/5 - Onshore Taranaki Basin overview. GNS Science Report 2009/58, 134p.

Lyon, G.L., W.F. Giggenbach, and Y. Sano, 1996, Variations in the chemical and isotopic composition of Taranaki gases and their possible causes: New Zealand Petroleum Conference Proceedings, v. 1, p. 171-174. 
Nicol, A., R. Carne, M. Gerstenberger, and A. Christophersen, 2011, Induced seismicity and its implications for $\mathrm{CO}_{2}$ storage risk: Energy Procedia, v. 4, p. 3699-3706.

Nicol, A., C. Childs, M.J.F. Lawrence, H. Seebeck, and J.J. Walsh, 2014, Assessment of the potential impact of faults and fractures on seal integrity for $\mathrm{CO}_{2}$ using New Zealand outcrop data. GNS Science consultancy report 2014/86; CO2CRC Report RPT13-4350, 24 p.

\section{Website}

NIWA, 2012, Submarine faulting beneath Pegasus Bay, March 5, 2012. Website accessed March 25, 2016,

https://www.niwa.co.nz/natural-hazards/research-projects/submarine-faulting-beneath-pegasus-bay 


\section{Feasibility of storing carbon dioxide on a tectonically active margin: New Zealand}

Field, B. ${ }^{1,2}$, Lawrence, M.1,2, Nicol, A. ${ }^{1,2}$, McNamara, D. ${ }^{2}$, Arnot, M.J. ${ }^{2}$, Coyle, F. ${ }^{1,2}$, Higgs, K.E.. ${ }^{1,2}$, Mountain, B. ${ }^{1,2}$, Gerstenberger, M. ${ }^{1,2}$, Daniel, R.. ${ }^{1,3}$, Bunch, M. ${ }^{1,3}$, Barton, B. ${ }^{4}$

${ }^{1}$ Cooperative Research Centre for Greenhouse Gas Technologies (CO2CRC), Melbourne ${ }^{2}$ GNS Science, Box 30368, Lower Hutt, New Zealand brad.field@gns.cri.nz ${ }^{3}$ Australian School of Petroleum, University of Adelaide, Australia ${ }^{4}$ University of Waikato

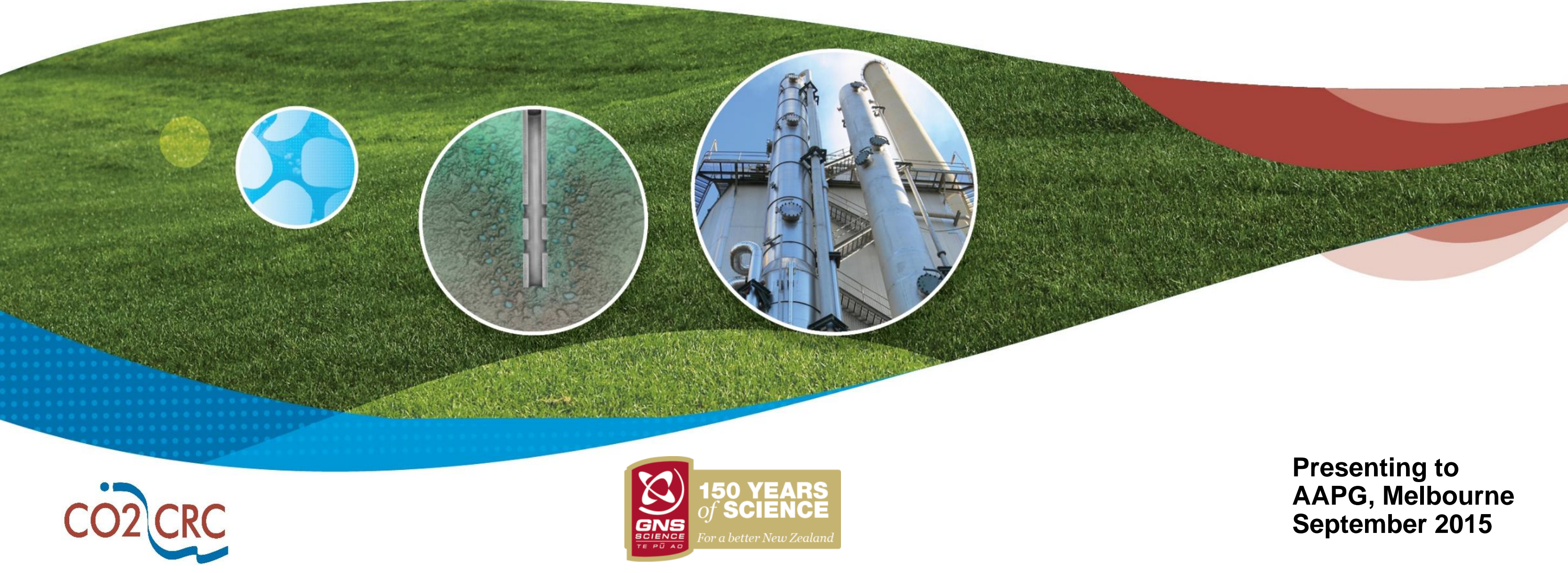


New Zealand is tectonically active

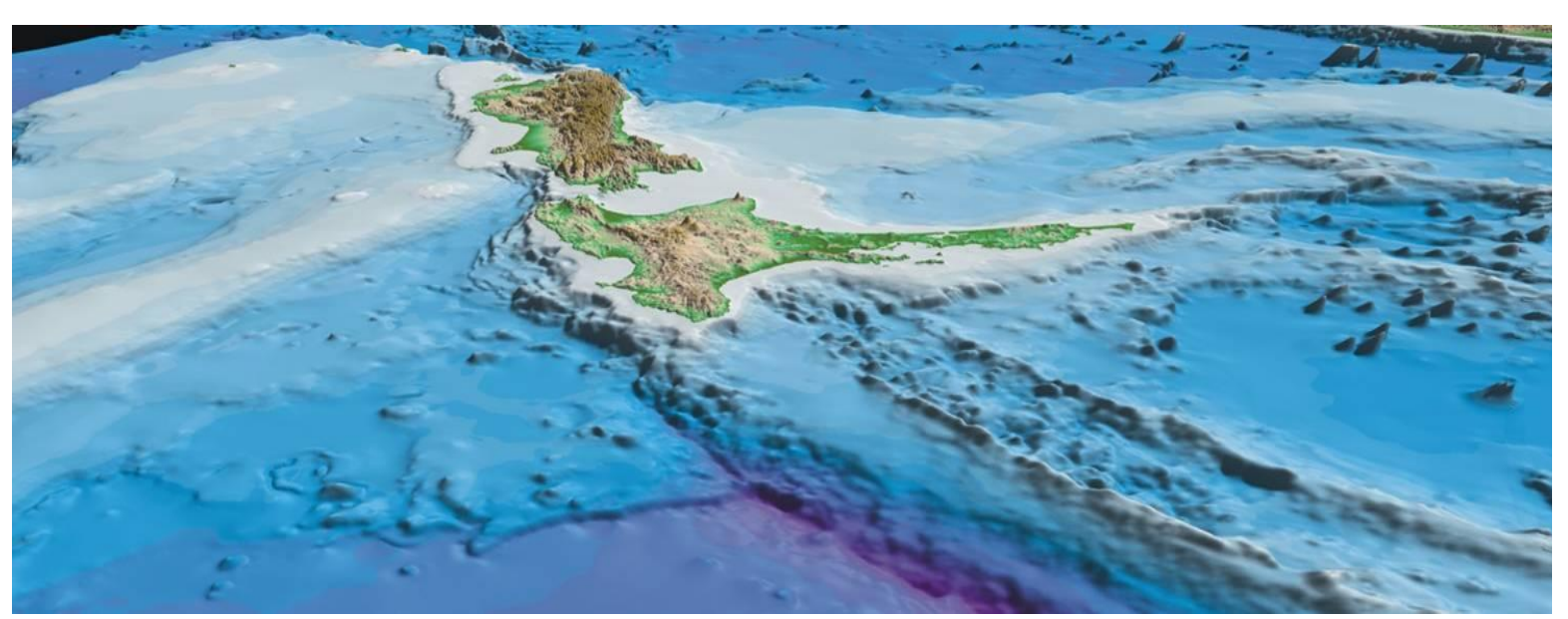

Ten years of deep

earthquakes in

New Zealand

(Depths $\geqslant 40$ km)

Generally 10 quakes per day

of magnitude $\geq 2$

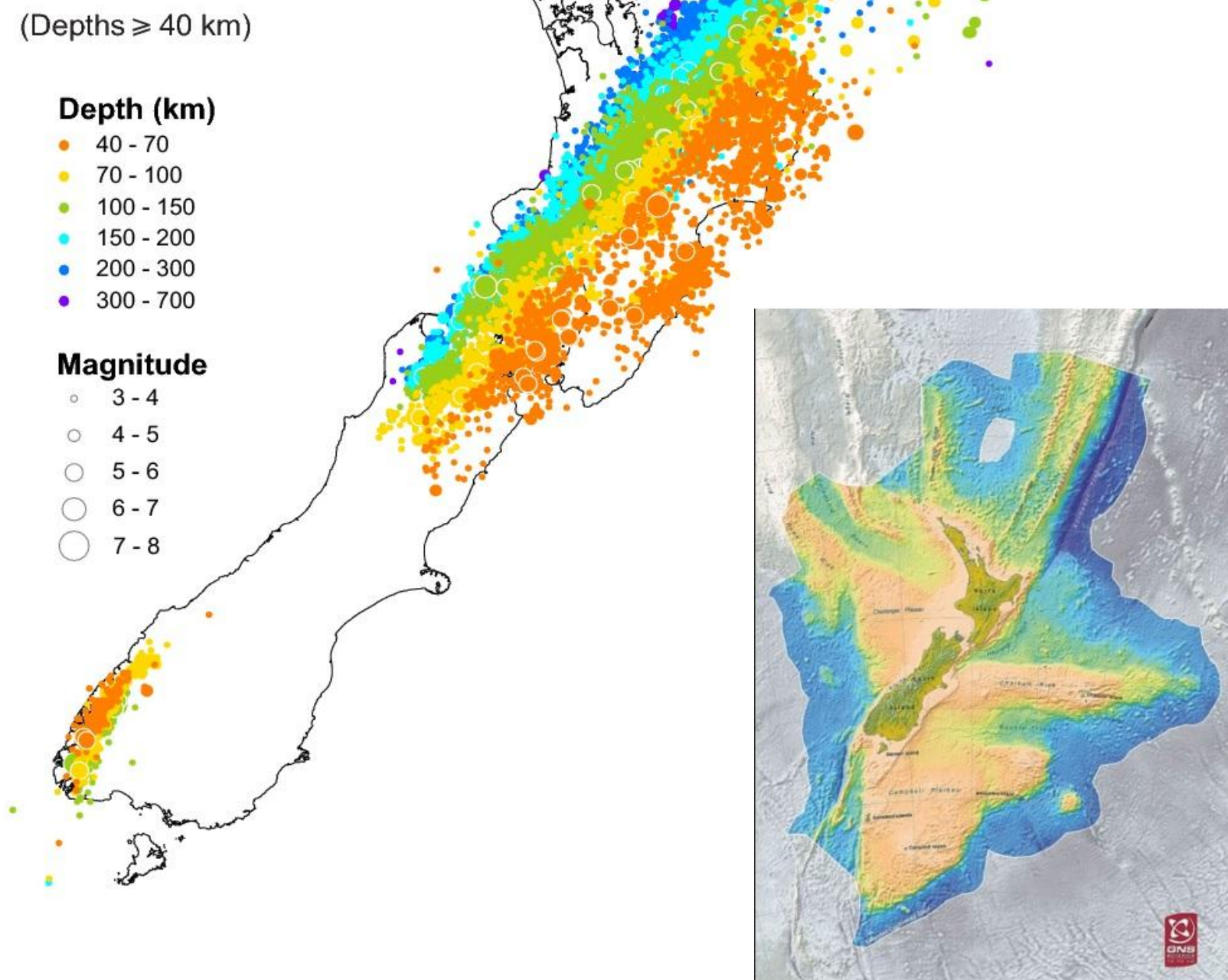




\section{Active plate margin storage has issues}

- Variable distribution of reservoir-seal pairs - less predictable;

- Locally overpressured reservoirs - injectivity;

- Reservoirs with immature mineralogies - fluid-rock reactivity;

- Fault and fracture densities, histories, permeabilities;

- Natural vs induced seismicity - distinction and prediction;

- Risk assessment - tailored to these issues;

- Societal concerns - induced seismicity; leakage?

- Regulations - public \& regulator assurance related to issues; economics of MMV. 


\section{Next big gas discovery might need stripping}

$\mathrm{CO}_{2}$ seeps, wells

Paritutu 75\%

Tuhua

McKee $\quad 4-6 \%$

Kaimiro $\leq 6 \%$

Ngatoro $\leq 54 \%$

Waihapa $16 \%$

Kapuni $\quad 44 \%$

Maui 1-18\%

Kupe $<1 \%$

Kotuku $86 \%$

\section{ls}

.

.

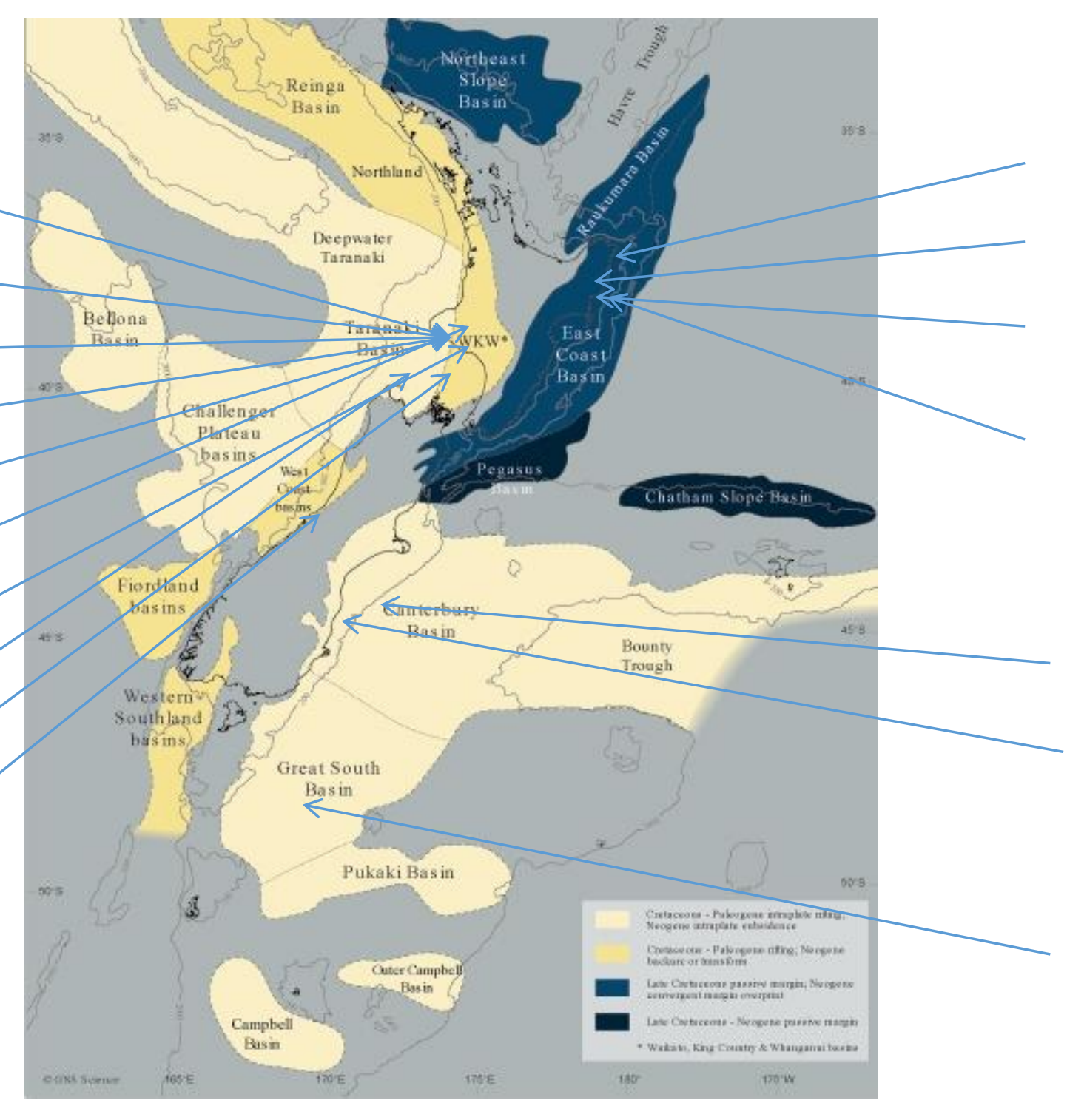

East Coast seeps

Otopotehetehe $\leq 10 \%$

Waitangi 0-9\%

Waimata $9 \%$

Morere $\leq 14 \%$

Canterbury

Clipper-1 11-20\%

Galleon-1 32\%

Great South Basin

Kawau-1A 7\%

After Lyon et al., 1991; Lyon 1996; Hulston et al., 1999 


\section{Taranaki - easiest?}

Estimates of storage capacity of fields when they become depleted, based on $100 \%$ replacement of the original recoverable hydrocarbons by $\mathrm{CO}_{2}$ :

\begin{tabular}{|l|c|}
\hline \multicolumn{1}{|c|}{ Field } & $\begin{array}{c}\mathrm{CO}_{2} \text { Storage } \\
\mathrm{Mt}\end{array}$ \\
\hline Kapuni & 106 \\
\hline McKee & 23 \\
\hline Rimu & 5 \\
\hline Mangahewa & 8 \\
\hline Waihapa/Ngaere & 4 \\
\hline Ngatoro & 3 \\
\hline Kaimiro & 2 \\
\hline
\end{tabular}

$174^{\circ} 0^{\prime} O^{\prime \prime} \mathrm{E}$

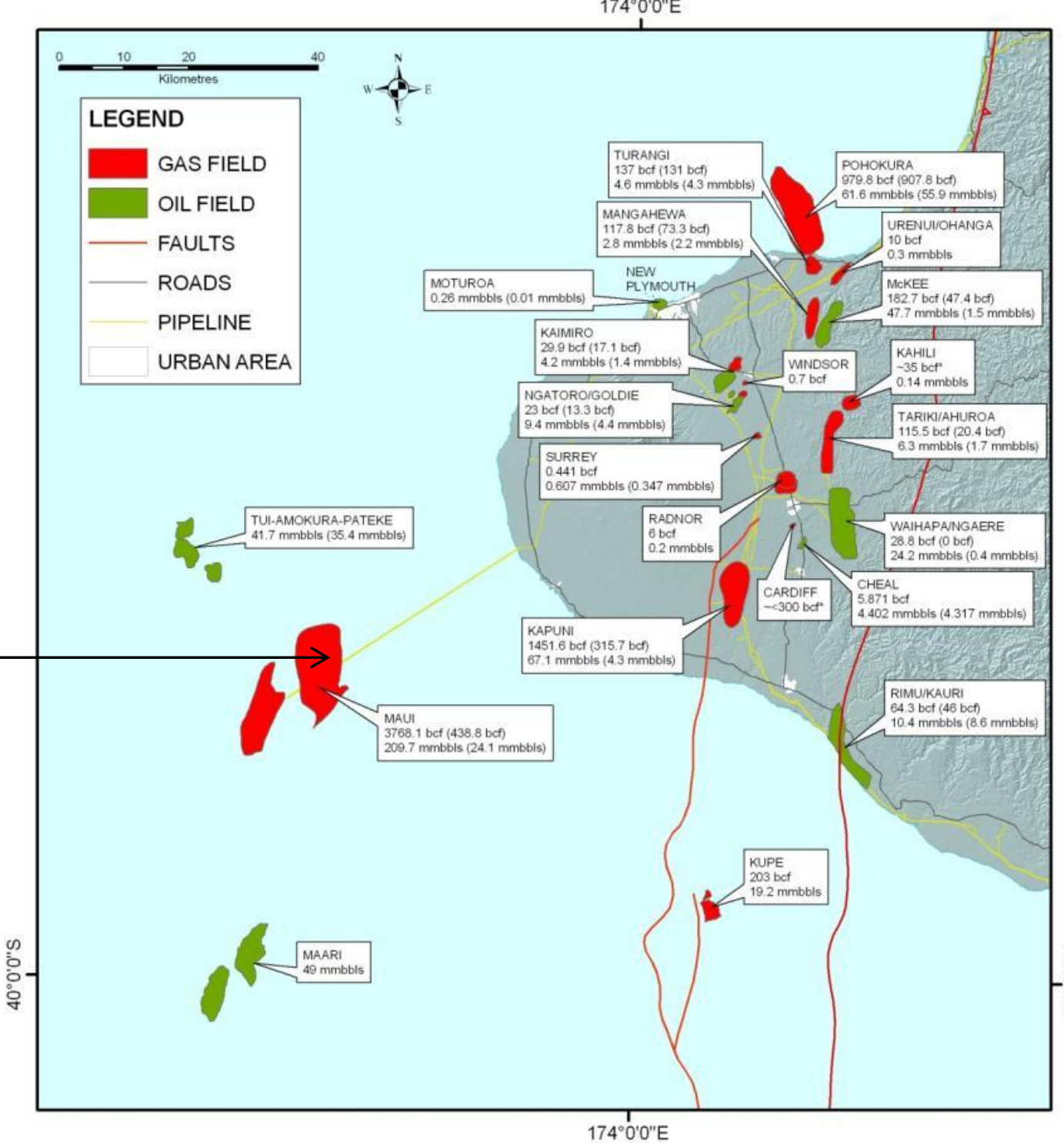

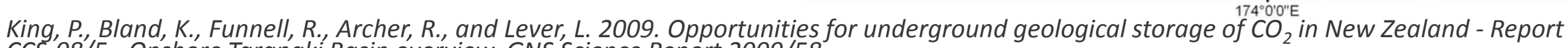
CCS-08/5 - Onshore Taranaki Basin overview. GNS Science Report 2009/58. 


\section{Regional storage opportunities (Projects completed 2009)}

Onshore capacity 15,000 Mt $\left(\operatorname{TPV}_{\mathrm{E}=1 \%}\right)$ $\mathrm{TPV}_{\mathrm{E}=1 \%}=$ Total Pore Volume discounted to $1 \%$ to allow for uncertainties in geological factors

Decades-worth of storage likely but detailed assessments needed

\section{Assumed stable settings....}

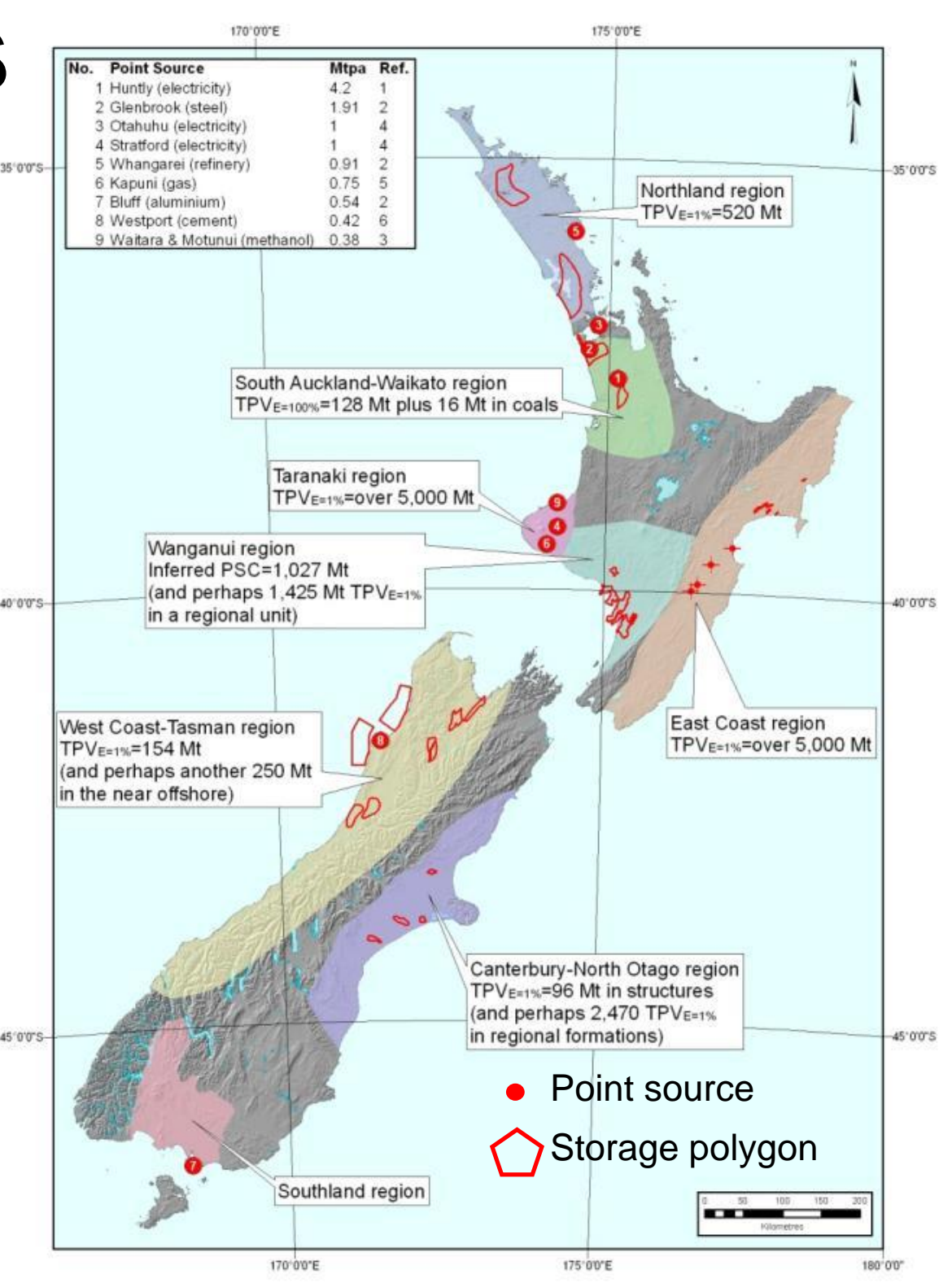

Field, B.D.; Arnot, M.J.; Begg, J.G.; Bland, K.J.; Bunch, M.; Doody, B.J.; Edbrooke, S.W.; Faulkner, R.; Funnell, R.H.; Griffin, A.G.; Higgs, K.E.; King, P.R.; Rattenbury, M.S.; Ricketts, B.; Strogen, D.P. 2009. New Zealand carbon dioxide storage site assessment. Phase 2. GNS Science consultancy report 2009/217; CO2CRC Report RPT09-1579. 50 p. 


\section{Variable distribution of reservoir-seal pairs}

Syndepositional and post-depositional structural events, particularly in regions close to the plate boundary (i.e., most of onshore New Zealand) $\rightarrow$ rapid facies changes; so extent of reservoir and seal facies uncertain at a regional scale.

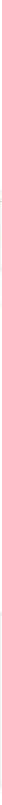

Field, B.D., et al. 2011, Geological transect across the Wairoa area : insights into elements of the East Coast petroleum system. GNS Science data series 11a. 1 CD. 


\section{High subsidence, uplift, sedimentation rates}

\section{East Coast basin overpressures}

Convergent margin = rapid subsidence with high sedimentation rates leading to overpressured reservoirs $\rightarrow$ injectivity issues?

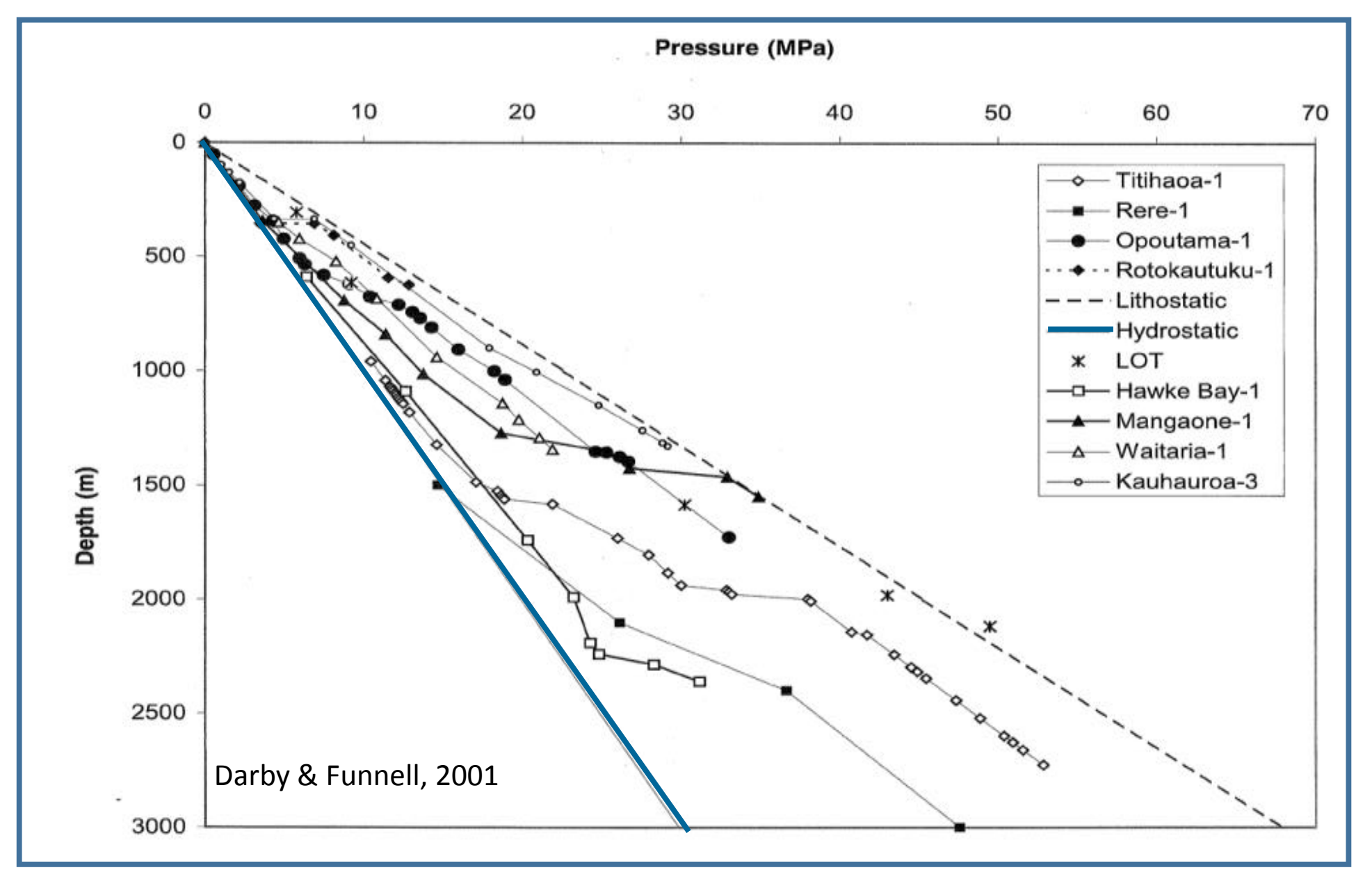




\section{Rock reactivity}

Many reservoirs compositionally immature, with a volcanic arc and/or greywacke components: likely to increase injected $\mathrm{CO}_{2}$-rock reactions.

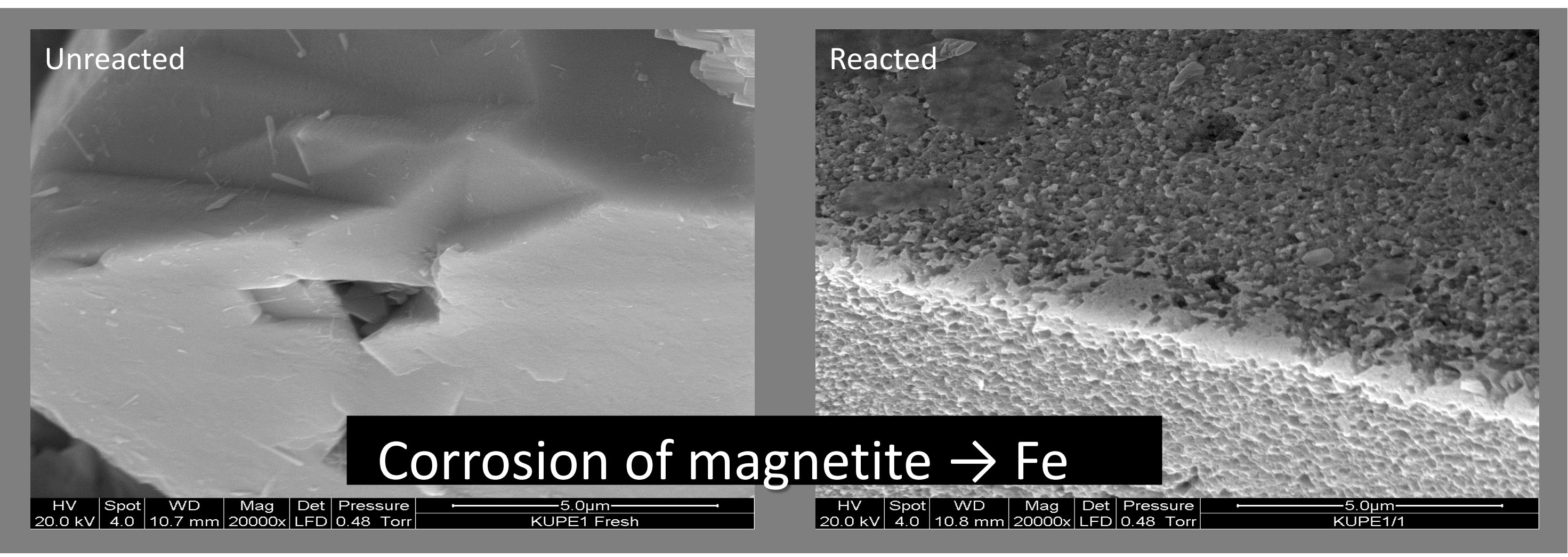

Laboratory experiments 


\section{Reactions can alter poro-perms}

Plagioclase reacts; no obvious changes in quartz, or sandstone texture on the grain size scale.
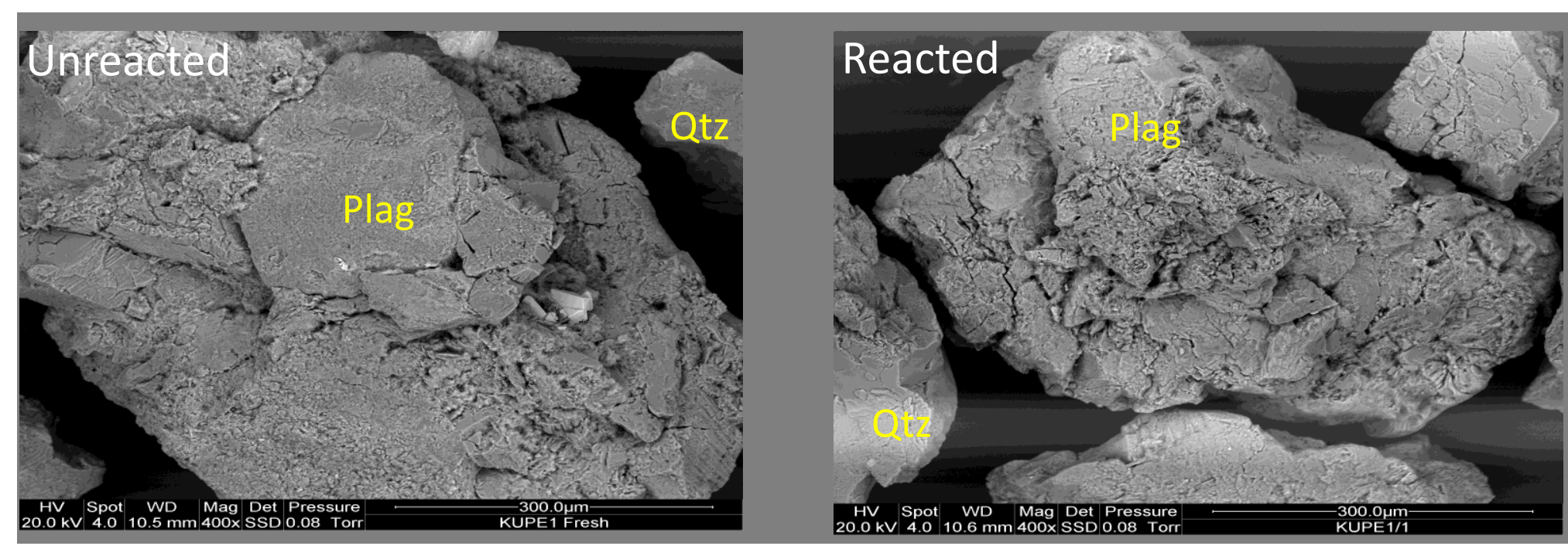

Dissolution of chlorite; Mg-Fe aluminosilicates.
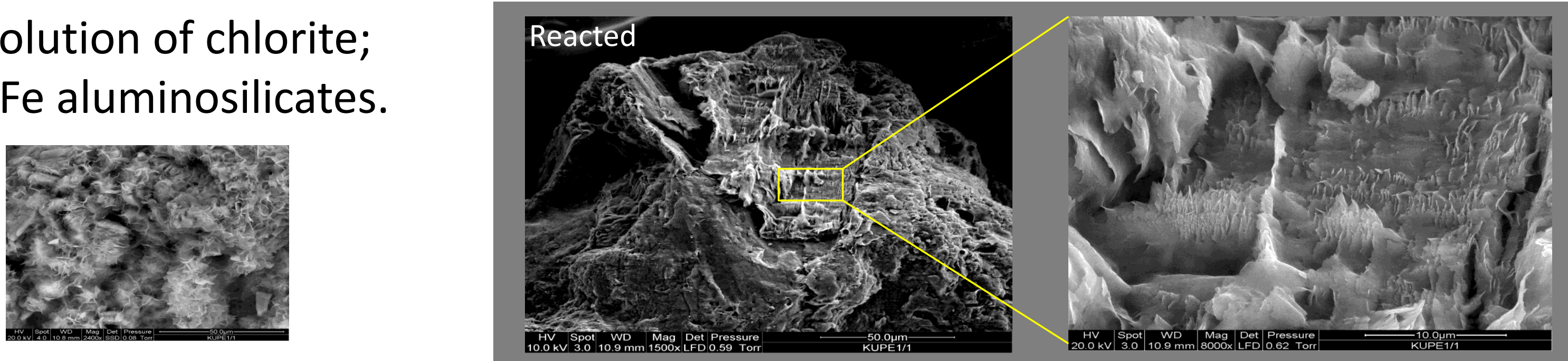

Six week reaction time with $\mathrm{CO}_{2}$-saturated fluid at $110^{\circ} \mathrm{C}$ 


\section{Active faults}

- Active faults onshore and offshore.

- Research is on-going: recognition, characterisation. Basement faults?

- Stress fields; dynamic; reactivations.

- Northland and Stewart Island - no known active faults onshore - but do not have good storage potential. Offshore Canterbury?

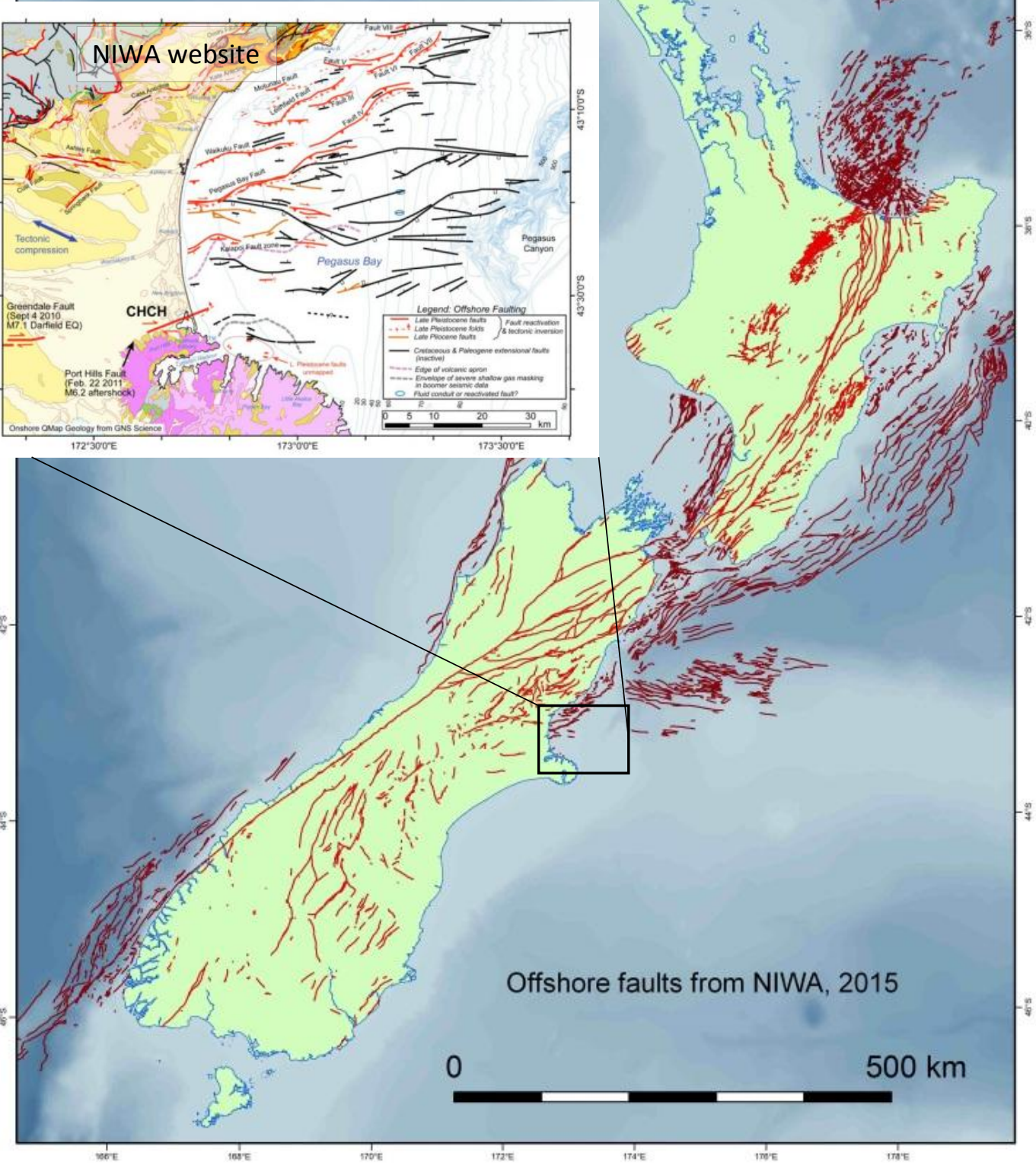




\section{Faults - detection and significance}

- Faults in seal vs reservoir; sealing/transmissive: plume?

- Scales of lengths and widths of faults in relation to seal thickness and dimensions;

- Complete offsets of seals vs leaky faults;

- Fault size related to seismicity?

- Seismic pumping?

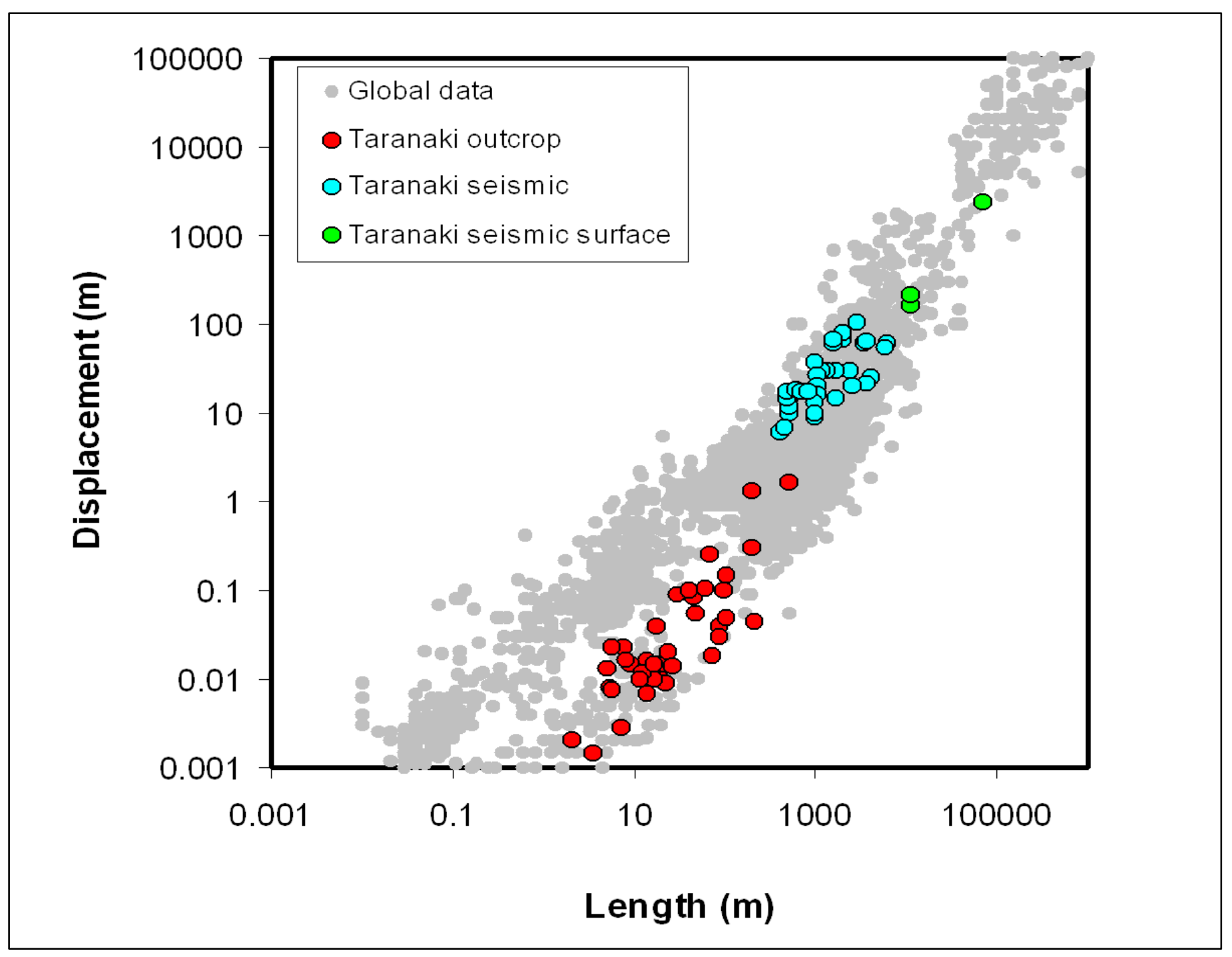




\section{Natural vs induced seismicity}

- Monitoring - distinguishing induced from natural seismicity is difficult!

- Baselines unreliable.

- Geonet - excellent for deeper quakes; not designed for hi-res shallow studies.
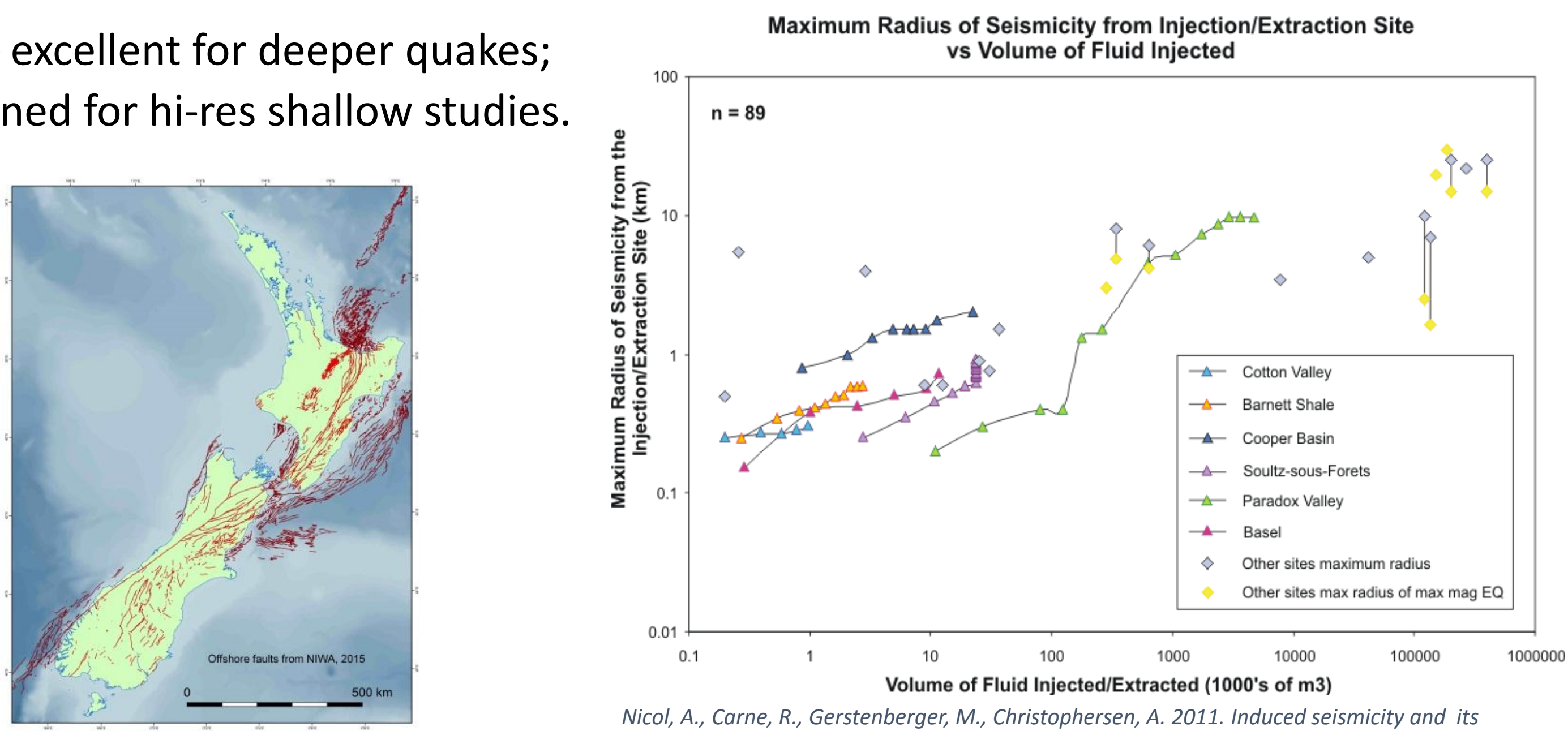


\section{Risk assessment}

\section{Greater emphasis on:}

- Complex reservoirs (facies and fractures);

- Challenging subsurface structure;

- Potentially leaky seals and faults;

- Stressed faults/induced seismicity;

- High anisotropic stress;

- Potential misconceptions - social licence

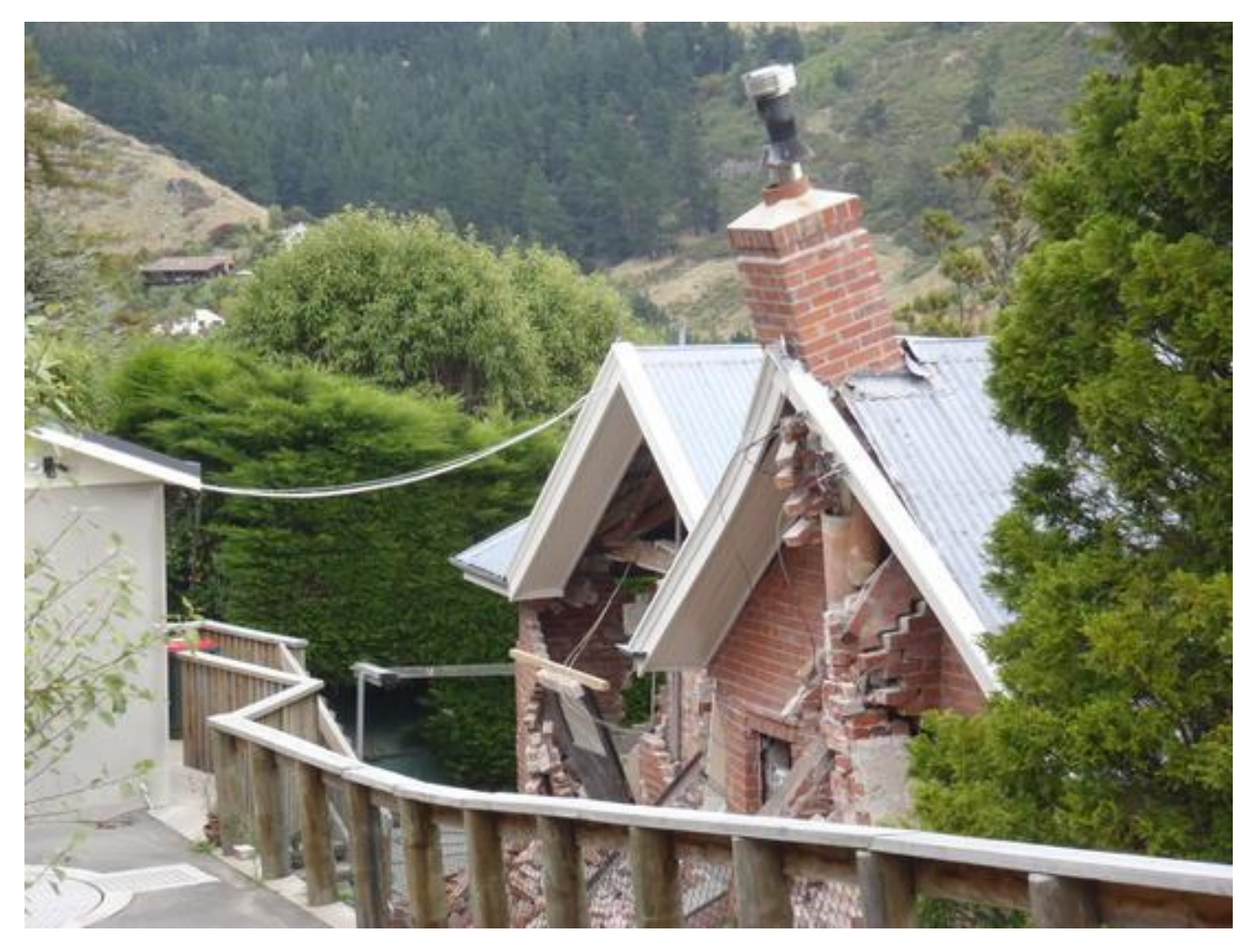
to operate. 


\section{Associated societal concerns}

- Oil town - Stratford: "Deliberative conference"

- Focus groups

- Māori iwi

- Regulator

- Companies

- Urban

- Rural

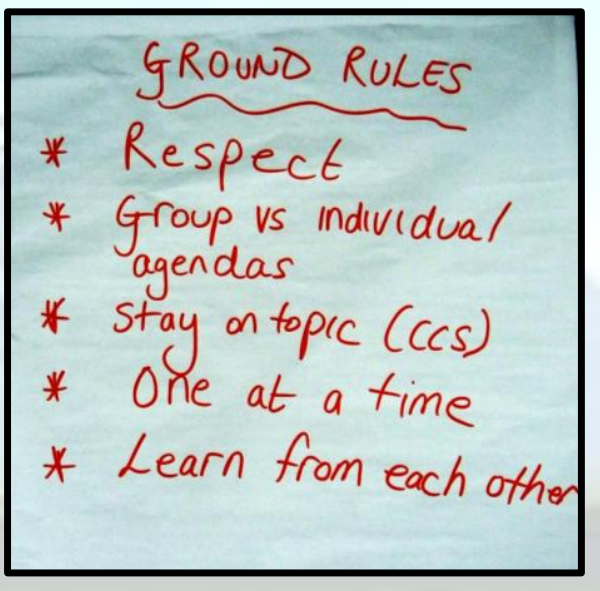

- Identification of commonalities and differences

- Foster informed understanding

- Group empowerment - identify issues and actions

- Results, feedback and uptake/applications

Active margin: increased concern over induced seismicity, risk of leaks.

\section{C.}

Carbon Capture and

Storage

Taranaki 2030

(FICTIONAL SCENARIO)

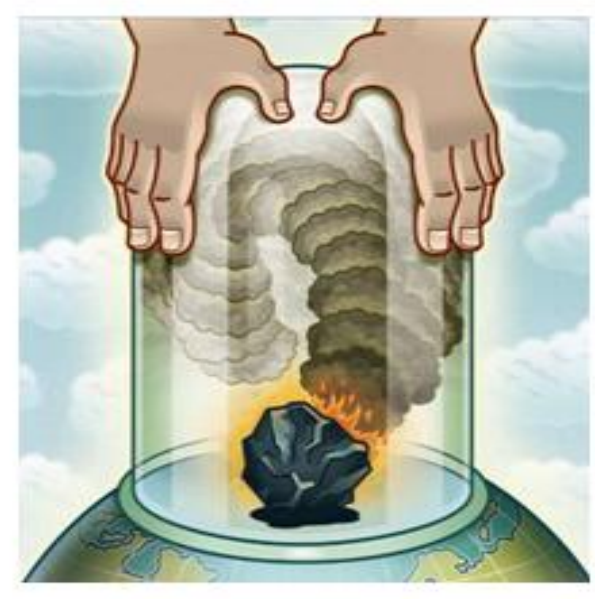

Tellus Enterprises 


\section{Regulatory issues}

Barton et al., 2013 study:

- Recommends a CCS Act

- Administration of Act $=$ who?

- Principles of Treaty of Waitangi

- Property rights (e.g., access)

- MMV*, other activities (oil/gas)* $^{*}$, transportation*, liabilities, ETS...

- Public and regulator assurance*; "CCS-ready"; EOR?

Carbon Capture and Storage:

Designing the Legal and Regulatory

Framework for New Zealand

Barry Barton, Kimberley Jordan and Greg Severinsen

with contributions from Nigel Bankes, Hans Christian Bugge,

Trevor Daya-Winterbottom, Robert Pritchard, and Valmaine Toki

September 2013

A report for the Ministry of Business, Innovation and Employment and the New Zealand Carbon Capture and Storage Partnership 


\section{Conclusions}

Active plate margin storage has issues:

- Variable distribution of reservoir-seal pairs;

- Local overpressuring;

- Fluid-rock reactivity;

- Faults, fracture density and complexity;

- Natural vs induced seismicity;

Yes, we can!

(probably)

(other active margins?)

- Risk assessment - tailored;

- Societal concerns - induced seismicity; leakage?

- Regulations - special issues: MMV, public \& regulator assurance; costs. 


\section{Government, Industry and Research Partners}

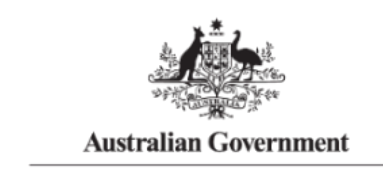

Department of Industry and Science

Government of Western Australia
Department of Mines and Petroleum
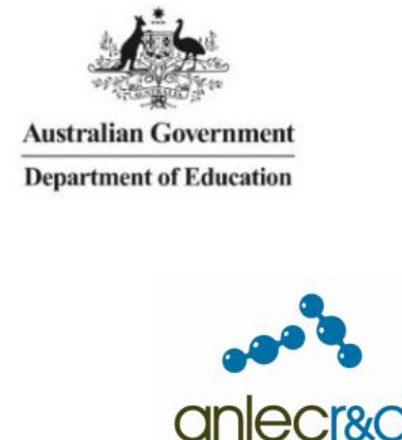

THE UNIVERSITY OF

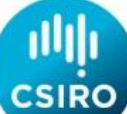

THE UNIVERSITY OF

WESTERN AUSTRALIA

2. Achieve International Excellence
UNSW

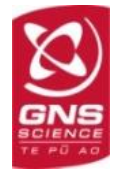

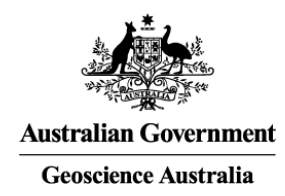

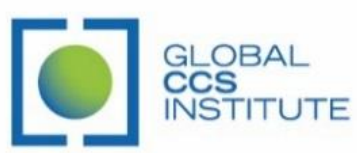

$\underset{\text { GOVRNMENT }}{\text { NSW }} \mid \begin{aligned} & \text { Trade \& } \\ & \text { Investment }\end{aligned}$

Chevron
Government of South Australia

\section{INPEX}

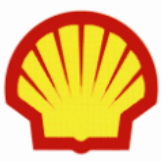

Curtin University

Federation

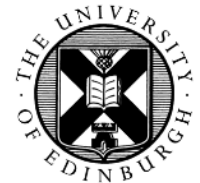

COAY21

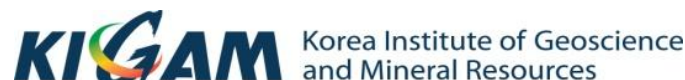




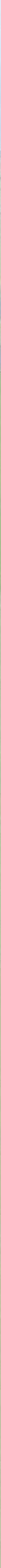

